\title{
VEREADOR NÃO PODE APENAS HOMOLOGAR A LEI ORÇAMENTÁRIA
}

Coluna publicada em 25.9.2012:<http://www.conjur.com.br/2012-set-25/ contas-vista-vereador-fundamental-elaboracao-lei-orcamentaria>

Avizinham-se as eleições municipais e, dentro de alguns dias, serão eleitos prefeitos e vereadores em todo o país. Há algumas semanas, assistimos ao horário eleitoral, em que proliferam as propostas com as quais os candidatos pretendem convencer o eleitorado.

Décadas se passam e chama a atenção, neste cenário, um fato bastante inusitado: o desconhecimento pelos candidatos a vereadores e também pelos eleitores das funçôes do Poder Legislativo Municipal e, por conseguinte, das atribuições que os vereadores exercerão assim que eleitos.

A competência dos municípios é bastante restrita e está, em sua maior parte, delineada nos artigos 30 e 31 da Constituição, sendo parte dessa competência exercida pelo Poder Legislativo ou com sua participação. Entre elas, destacam-se: a) legislar sobre assuntos de interesse local; b) suplementar a legislação federal e estadual no que couber; c) legislar sobre tributos municipais; e d) legislar em matéria de ordenamento territorial, planejamento, uso e ocupação do solo urbano, dentre outras. ${ }^{1}$

O exercício dessa competência, no mais das vezes, não é muito intenso. Não são muitos, e nem sempre relevantes, os assuntos de interesse local que exigem leis para serem regulados; os tributos municipais, por sua vez, em regra, têm legislação estabilizada, exigindo poucas alteraçôes, sem contar a pequena margem que lhes resta para inovações, em função do detalhamento da legislação complementar, como é o caso do ISS. Em alguns municípios, há maior relevância, efetivamente,

1 Constituição Federal, artigo 30, com as adaptações cabíveis. 
na legislação sobre uso e ocupação do solo, talvez um dos poucos itens dessa breve lista que exigem uma participação mais efetiva do legislador municipal.

Como se vê, são poucas as atribuições de um vereador. Infelizmente, pois nenhum político está mais próximo do povo que o vereador. Nenhum político é capaz de identificar com mais precisão as reais necessidades da população, levando, portanto, a voz do povo para dentro da administração pública.

Pior é ver que essas atribuições, já pequenas, são, por vezes, indevidamente reduzidas. Cito como exemplo a generalizada ideia de que não têm eles iniciativa legislativa em qualquer projeto que envolva despesa pública, concessões de incentivos fiscais e outras que tratam de matéria financeira. Ficam tolhidos em sua capacidade de apresentar projetos de lei, já que, no mais das vezes, estes referem-se às matérias citadas. E, por incrível que pareça, injustificada e inexplicavelmente, pois tal entendimento não passa de verdadeiro boato! Não há qualquer plausibilidade jurídica nessa tese sobre a qual já discorri longamente ${ }^{2}$ e, desta feita, remeterei o leitor ao texto já publicado, para oportunamente voltar ao tema.

Há que se ressaltar, ainda, dois pontos relevantes em que se observam graves desconhecimentos a respeito das atribuições de um vereador, integrante do Poder Legislativo Municipal.

O primeiro deles é a clareza quanto à sua função como membro do Poder Legislativo. Ou seja, as atribuiçôes do vereador limitam-se ao que compete ao Poder Legislativo, o que muitos parecem desconhecer tal a quantidade de manifestações e promessas que envolvem atribuiçóes de outros poderes, especialmente o Executivo. Vereador é eleito para cumprir as funções que lhe cabem como legislador, tais como as que foram sucintamente enumeradas nos parágrafos anteriores.

Evidente que, em sendo um legítimo representante da população, age bem em fazer chegar ao Poder Executivo as necessidades daqueles que o elegeram, mas essa não é sua verdadeira função. E, como se verá a seguir, há meios mais adequados que lhe permitem atender ao interesse público que estão no âmbito de suas atribuições constitucionais.

O segundo ponto relevante é a consciência de que integra o Poder Legislativo Municipal. O Brasil é uma Federação e, como tal, composta de entes federativos de três esferas: federal, estadual e municipal. Há divisão de competências, recursos,

2 CONTI, José Mauricio. Iniciativa legislativa em matéria financeira. CONTI, José Mauricio; SCAFF, Fernando F. (coords.) Orçamentos públicos e direito financeiro. São Paulo: RT, 2011, p. 283-307. Ver também coluna Parlamentar pode, sim, propor lei em matéria financeira, publicada em 4 de julho de 2013. 
encargos, de modo que cada esfera de governo tem sua competência delimitada pela Constituição. Os esforços dos vereadores hão de se concentrar naquilo que é da alçada municipal, pois são outros os representantes legitimados a agir na esfera estadual e federal.

Por outro lado, há competências da maior relevância a serem exercidas pelos vereadores, e o que se nota é o desconhecimento a respeito delas. A principal é justamente a atuação no âmbito das finanças públicas.

O orçamento público é a lei anual, que define os gastos públicos. Quanto se vai gastar, onde vai ser aplicado o dinheiro, quem vai fazê-lo e para quê. É lei, de iniciativa do prefeito, mas submetida à aprovação pela Câmara, cabendo aos vereadores debatê-la, com poderes para apresentar emendas e adequar o projeto encaminhado pelo Poder Executivo aos reais interesses da população. Os recursos públicos municipais só poderão ser gastos se previstos no orçamento. Ou seja, toda e qualquer ação governamental municipal que importe em despesa tem de estar contemplada na lei orçamentária. Em suma: os vereadores têm a palavra final para decidir o que será feito com todo o dinheiro público municipal!

E mais: cabe ao Poder Legislativo municipal fiscalizar as contas públicas, pois é o titular do controle externo da administração municipal, e julgará anualmente as contas apresentadas pelo Prefeito. ${ }^{3}$ Dispõe de poderes de fiscalização da atividade financeira da administração pública municipal, cabendo-lhe analisar, investigar, denunciar irregularidades, enfim, exercer na plenitude seus poderes como fiscais do dinheiro público. Um julgamento desfavorável das contas gera consequências extremamente graves, evidenciando a relevância da decisão. $\mathrm{O}$ reconhecimento da regularidade das contas, por outro lado, em tese, demonstra que a lei orçamentária foi fielmente cumprida, tendo sido o dinheiro público correta e adequadamente aplicado. Em outras palavras: aos vereadores compete definir o que será feito com o dinheiro público e fiscalizar sua correta destinação. Desnecessário dizer, a esta altura, que os vereadores cumprem a mais relevante função no âmbito municipal, representada pela deliberação, aprovação e fiscalização do orçamento público municipal.

É oportuna a pergunta, que deixo ao leitor e eleitor responder: quantas vezes se viu na propaganda eleitoral referência ao exercício dessas atribuições?

Por essas razões, é importante que vereadores e eleitores procurem se informar a respeito das reais funçôes do Poder Legislativo Municipal, bem como das competências e encargos afetos aos municípios. Os Poderes públicos têm o dever de

3 Constituição Federal, artigo 31. 
esclarecer melhor a população a respeito dessas informações, permitindo ao eleitor escolher correta e conscientemente seu candidato e, ao vereador, exercer melhor a sua função, fazendo valer, sem distorções, o princípio democrático expresso no artigo $1^{\circ}$ de nossa Constituição.

Deve ainda ser uma luta de todos tornar efetivas as funções dos vereadores, permitindo que exerçam na plenitude seu mandato, sem subterfúgios que mitiguem seu poder que já não tem a dimensão merecida.

Cito, apenas para exemplificar, os orçamentos municipais.

Têm os vereadores hoje, na esmagadora maioria dos municípios, uma ínfima participação na elaboração e execução da lei orçamentária, em função de costumes arraigados que praticamente anularam a participação e influência dos vereadores naquilo que é a sua mais relevante função. Leis orçamentárias são aprovadas com altíssimas margens de remanejamento, ${ }^{4}$ tornando-as quase inúteis como peças legislativas, por transferir ao prefeito o poder de alterá-las sem necessidade de autorização da Câmara e fazendo com que os orçamentos públicos, que há alguns anos eram verdadeiras peças de ficção, continuem se portando como tais na maior parte dos municípios.

Vê-se a concessão de pequenas verbas a título de dotação para atender emendas parlamentares, transformando o poder de decidir sobre as despesas públicas em uma disputa por verdadeiras migalhas e anulando qualquer iniciativa de interferir nas políticas públicas municipais. Sem contar os municípios em que não há dotação alguma para as emendas parlamentares, reduzindo a participação dos vereadores à mera homologação da proposta orçamentária.

É oportuno o momento para esta reflexão, pois já passou da hora de resgatar a importância e dignidade das funções daquele que é o político mais próximo do povo, representante mais fiel das necessidades da sociedade.

4 Autorizações antecipadas para que o Poder Executivo abra créditos suplementares, nos termos do art. $7^{\circ}$ da Lei 4.320/1964. 